\title{
Has Financial Policy Intervention Benefited Local Society Affected by Natural Disaster?: Questioning the Utilitarian Approach
}

\author{
Ketut Sukawati Lanang Putra Perbawa* \\ Faculty of Law, Mahasaraswati University-Bali, Indonesia
}

Article Received: 29th Juni 2019; Accepted: 27th July 2019; Published: $31^{\text {st }}$ July 2019

\begin{abstract}
Mount Agung eruptions have an impact on economic losses, especially the banking sector in Bali. Entrepreneurs and bank debtors, especially in Karangasem Regency and its surroundings, ask for relief from the implementation of the provisions of their credit agreements in terms of time, interest and also obligations performance. It is a legal research that focuses on analyzing the utilitarian approach used by the Indonesian Financial Services Authority (Otoritas Jasa Keuangan/OJK) in the form of Banking-relaxation policy in supporting the local society who affected by natural disaster. It has been concluded that local society who affected by the eruption of Mount Agung in Karangasem Regency Bali may use 'force majeure' to suspend their obligation performance in any economic matters, including loan banking. In addressing this issue, OJK plays a role by issuing financial policy for the 3 years period that is expected to give a margin of appreciation for local society to re-arrange their economic situation after the disaster. Such policy, seems has not properly been implemented by all banks in related area. Therefore, a utilitarian approach that inspired the OJK financial relaxation policy should be improved by taking into consideration the concerns on cultural-economic issues, the real declining and uncertain situation of the local economy, and the fragile tourism industry in Karangasem regency.
\end{abstract}

Keywords: Natural disaster; financial service authority; financial relaxation policy; local society, utilitarian approach.

How to cite (Chicago 16th): Putra Perbawa, Ketut Sukawati Lanang. "Has Financial Policy Intervention Benefited Local Society Affected by Natural Disaster?: Questioning the Utilitarian Approach." Udayana Journal of Law and Culture 3, no. 2 (2019): 204-222. https://doi.org/10.24843/UJLC.2019.v03.i02.p05.

doi: https://doi.org/10.24843/UJLC.2019.v03.i02.p05

\footnotetext{
*Email/Corresponding Author: sukawatilanang@gmail.com
} 


\section{Introduction}

For the last three years, Mount Agung volcano eruptions have an impact on economic losses, especially the banking sector in Bali. In 2017, the ratio of banking Non-Performing Loan (NPL) in the Province of Bali is 3,42 percent, higher than the national average NPL which reached 2.59 percent. ${ }^{1}$ In December 2017, the Association of Indonesian Rural Banks of Bali released that 24 bank perkreditan rakyat/BPR (hereinafter referred to as rural banks) were affected by the eruption of Mount Agung, four of which were quite seriously affected because they had not temporarily operated. What they may offer to the affected debtors at that time was by conducting credit restructuring that includes correcting the value of obligations such as the basic, time period, and interest. ${ }^{2}$

In the beginning phase of the disaster at the end of the year of 2017, the government seemed merely focusing on providing emergency response assistance as there are many peoples left their home seeking safer shelters. It is quite obvious that there were relatively no programmatic economic incentives from the government. Entrepreneurs and bank debtors, especially in Karangasem Regency and its surroundings, ask for relief from the implementation of their loan agreement provisions in terms of time, interest and also obligations performance.

Responding to the economic situation, the Karangasem Regency Government officially requested the Financial Services Authority to provide relaxation for banking customers who had difficulty to pay their loan because of the eruptions of Mount Agung. ${ }^{3}$ Furthermore, the Regent of Karangasem Regency held a meeting with the Financial Services Authority, the Indonesian Chamber of Commerce of the Bali Province, the Hotel and Restaurant Association, the Bali Cooperative Office and the Karangasem Regency businessman to discuss the incapability of more than 71.000 Karangasem residents, who left their home and lost their livelihood due to the eruption, to pay their banking loan. In that meeting, the Regent of Karangasem Regency explicitly asked the Indonesian Financial Services Authority (Otoritas Jasa Keuangan/OJK) that residents who live in an area around 8 to $10 \mathrm{~km}$ from the

1 Nusabali.com. Berita. Kredit Bermasalah di Bali Lampaui Nasional. https://www.nusabali.com/berita/25259/kredit-bermasalah-di-bali-lampaui-nasional

2 Wartaekonomi.co.id. Kabar Finansial. Perbarindo Harapkan Dampak Gunung Agung Tidak Pengaruhi NPL. https://www.wartaekonomi.co.id/read163744/perbarindo-harapkandampak-gunung-agung-tidak-pengaruhi-npl.html

3 Bali.bisnis.com. Bisnis Bali dan Nusra. Karangasem Resmi Ajukan Relaksasi Kredit. https://bali.bisnis.com/read/20171106/538/772049/karangasem-resmi-ajukan-relaksasikredit 
summit of Mount Agung be free of principal and interest on loans and citizens who live outside those area only pay $50 \%$ of the interest. 4

A specific banking sector policy was then issued following the impact of this natural disaster after Indonesian OJK determined Karangasem Regency as an area that requires special treatment of bank loans for three years, starting December 29, 2017.5 This policy was issued by referring to Regulation of Indonesian Financial Services Authority No. 45/POJK.03/2017 on Special Treatment of Credit or Bank Financing for Certain Areas in Indonesia Affected by Natural Disasters.

This article focuses on analyzing the utilitarian approach used by OJK in the form of Banking- financial relaxation policy in supporting the local society affected by natural disaster. The article cites many law and regulations, especially those issued by OJK. The analysis which is conducted based on a long observation by author who during the disaster period became an independent commissioner of a commercial bank in Bali. This article is begun by discussing a basic legal notion on 'force majeure' (overmacht) that is generally associated with the common understanding of not imposing a strict performance of a contractual obligation under private laws in case of unforeseen and unexpected situation, in this case a natural disaster, that might have an impact to debtor. It continues with a general description of how OJK plays a role in addressing Natural disaster. A specific analysis is then focused on the implementation of OJK policy in Karangasem Bali. This paper establishes an argument that the uniqueness of the economic situation in Bali, that is very much influenced by the peculiarity of its social and cultural life of the local peoples, should be taken into consideration by relevant financial authorities in issuing a policy to address financial problems faced by those who affected by natural disasters.

There have been some research done relating to the topics of the present paper. Some studies discussed the risk-based capital ratio after the natural disaster of the independent banks in the area of disaster ${ }^{6}$ while some others focused on how banks adjust their asset structure in response to changes in

\footnotetext{
4 Oke Finance. Economy. OJK Diminta Bebaskan Bunga Kredit bagi Pengungsi Gunung Agung, $\quad$ https://economy.okezone.com/read/2017/12/26/320/1835879/ojk-dimintabebaskan-bunga-kredit-bagi-pengungsi-gunung-agung

${ }^{5}$ Hukumonline.com. Berita. OJK Tetapkan Karangasem Bali dalam Perlakuan Khusus Soal Kredit Bankhttps://www.hukumonline.com/berita/baca/1t5a4c8d7c228b4/ojk-tetapkankarangasem-bali-dalam-perlakuan-khusus-soal-kredit-bank/

${ }^{6}$ Ulrich Schüwer, Claudia Lambert, Felix Noth, "How do banks react to catastrophic events? Evidence from Hurricane Katrina." Review of Finance 23, no. 1 (2018): 75-116
} 
loan demand after natural disasters. 7 Haeva Hadi et.al conducted legal research that analyzes the obstacles that occur in the implementation of the agreement on Home Loan (KPR) after severe damaged due to the earthquake that occurred in North Lombok Regency, Province of West Nusa Tenggara. 8 Pujiyono et.al study Issues on the Implementation of the Regulation of Financial Service Authority with regards to the dispute of non-performed small and micro loans due to a natural disaster. ${ }^{9}$ Felix Noth and Ulrich Schuwer explored whether or not natural disasters affect bank stability and found that disaster damages in the banks' business regions indeed weaken bank stability and performance. 10 Norman I. Silber, addresses inequities in the apportionment of losses that arise when traditional rules of consumer finance are applied to enforce payment obligations that accrue during and after catastrophes and explores the contracts and debt obligations of those who would be affected in another disaster of similar or even greater magnitude and duration and suggests a reform that could ameliorate foreseeable consumer finance difficulties in a manner consistent with contemporary approaches to consumer protection. ${ }^{11}$

\section{Result and Analysis}

\subsection{Natural Disaster and the Clause of Force Majeure}

There is a common understanding that the inability of the debtor to pay their loans due to earthquakes, flash floods, and the presence of lava/eruption of Mount Agung should be connected to the concept of force majeure. Force majeure simply means "an event or effect that cannot be reasonably anticipated or controlled." 12 This phrase commonly used in the field of law to refer to "an unexpected event such as a war, crime, or

7 Jaap Bos, Runliang Li, and Mark Sanders. "Hazardous Lending: The Impact of Natural Disasters on Banks' Asset Portfolio." (2018).

8 Haeva Hadi, Zainal Asikin, Muhammad Sood. Agreement on Home Loan (KPR) Due to Natural Disaster (Case Study in North Lombok Regency)." International Journal of Multicultural and Multireligious Understanding 6, no. 3 (2019): 267-276.

9 Pujiyono, M Najib Imannullah, Ryan Ganang Kurnia, "Problematika Pelaksanaan Pojk Nomor 45/POJK. 03/2017 Dalam Penyelesaian Kredit Kecil dan Mikro Yang Macet Karena Bencana Alam." Jurnal IUS Kajian Hukum dan Keadilan 6, no. 3 (2018): 466.

10 Noth, Felix; Schüwer, Ulrich. "Natural Disaster and Bank Stability: Evidence from the US Financial System." SAFE Working Paper, No. 167. (2018).

11 Norman I. Silber, Debts, Disasters, and Delinquencies: A Case for Placing a Mandatory Force Majeure Provision into Consumer Credit Agreements." NYU Rev. L. \& Soc. Change 34 (2010): 760-792.

12 Merriam-Webster. https://www.merriam-webster.com/dictionary/force\%20majeure 
an earthquake which prevents someone from doing something that is written in a legal agreement" 13

One can be given relief in an agreement because of the existence of a force majeure, which is a matter/condition or clause that can be used in providing relief or reducing performance (obligations in the agreement) of the parties. Force majeure is one of the clauses that are usually in an agreement, said one clause because the position of force majeure in an agreement is in the main agreement, not separate as an additional agreement and associated with the main agreement as an agreement. A Force Majeure clause refers to "contract provision that allows a party to suspend or terminate the performance of its obligations when certain circumstances beyond their control arise, making performance inadvisable, commercially impracticable, illegal, or impossible."14

Indonesian civil code does not regulate in a formal manner about force majeure but rather regulates force majeure in relation to compensation for loss and interest. Whatsoever, general conclusions can be drawn from special arrangements. This can be seen in the regulation section on compensation, or risk regulation due to force majeure for unilateral contracts or in special contracts.

Article 1244 of the Indonesian Civil Code mentions that "If there is any reason for such, the debtor is compensated for costs, damages, and interests if he cannot prove, that the non-performance or the late performance of such obligation, is caused by an unforeseen event, for which he is not responsible and he was not acting in bad faith." Further, Article 1244 of Indonesian Civil Code regulates that "The debtor needs not to compensate for costs, damages or interests if an act of God or an accident prevented him from giving or doing an obligation, or because of such reasons he committed a prohibited act"

The elements of force majeure in the Indonesian Civil Code can be detailed as follows: First, the event that causes the occurrence of force majeure must be "unexpected" by the parties, or not included in the basic assumption when the parties make the contract (Article 1244 of the Indonesian Civil Code ); Second, the event cannot be accounted for by the party who must carry out the presentation (the debtor) (Article 1244 of the Indonesian Civil Code); Third, events that cause force majeure are outside the fault of the debtor (Article 1244 of the Indonesian Civil Code); Fourth, the event that caused the force majeure was not a deliberate incident by the debtor. This is an inaccurate formulation,

13 Cambridge Dictionary. https://dictionary.cambridge.org/dictionary/english/force$\frac{\text { majeure }}{14}$ 
the cause of which should be "beyond the fault of the parties (Article 1545 of the Indonesian Civil Code), not accidentally". Because, the mistakes of the parties are either done intentionally or unintentionally, namely in the form of "negligence" (negligence); Fifth, the parties are not in a state of bad faith (Article 1244 of the Indonesian Civil Code). ${ }^{15}$

The qualification of natural disaster as a type of force majeure, as usually appears is the clause of the contract, makes the non-performing loans are credit risk in the banking business. ${ }^{16}$ One of them is due to natural disasters and this is a force majeure where the presence of unexpected events that occurred outside the fault of the debtor after entering into the agreement, these events preclude the debtor from fulfilling his achievements before debtor is declared to be negligent and therefore the debtor cannot be blamed and do not bear the risk for such events. Natural disasters are included in the clause of force majeure. ${ }^{17}$

\subsection{The Role of Indonesian Financial Services Authority in Addressing Natural Disaster}

The establishment of Indonesian Financial Services Authority (Otoritas Jasa Keuangan/OJK) was aimed at ensuring the activities in the financial services sector to be implemented in an organized, fair, transparent and accountable manner, capable of realizing the financial system that grows in a sustainable and stable manner, and capable of protecting the consumers and society interests. ${ }^{18}$ The creation of OJK enables the Central Bank of Indonesia to focus on monetary management and do not need to deal anymore with bank supervision matters as a sector in the economy. ${ }^{19}$ Article 5 makes clear that the functions of OJK are to establish an integrated regulatory and supervisory system for all activities in the financial services sector. OJK performs its regulatory and supervisory duties over: ${ }^{20}$

a. financial services activities in the Banking sector;

b. financial services activities in the Capital Market sector; and

${ }^{15}$ Agri Chairunisa Isradjuningtias, Force Majeure (Overmacht) Dalam Hukum Kontrak (Perjanjian) Indonesia, Veritas et Justitia1 no.1 (2015): 136-154.

16 See Rudy Haposan Siahaan, "Natural Disaster as The Reason To Writing Off Banking Credit In Indonesia." Brawijaya Law Journal 1, no. 1 (2014): 14-25,

17 Ibid. Art. 4.

${ }^{18}$ Law of the Republic of Indonesia No. 21 Year 2011 on Financial Services Authority, 2014. 43

19 Adrian Sutedi, Aspek Hukum Otoritas Jasa Keuangan. Jakarta: Raih Asa Sukses, Art. 6.

${ }^{20}$ Law of the Republic of Indonesia No. 21 Year 2011 on Financial Services Authority, 
c. financial services activities in the sectors of Insurance, Pension Fund, Financing Institutions, and Other Financial Services Institutions.

OJK is authorized to take necessary actions to prevent consumers and public from losses by ordering the Financial Services Institutions to terminate their activities if such activities are potential to cause losses to the public and by taking other actions deemed necessary in accordance with the provisions of laws and regulations in the financial services sectors. ${ }^{21}$ In substance, authorities given to OJK reflects constitutional mandate that aims to ensure that the financial services sector is orderly, orderly, fair, transparent and accountable, which in turn creates a stable and sustainable financial system. ${ }^{22}$

With regards to natural disaster, OJK issued Regulation of Indonesian Financial Services Authority No. 45/POJK.03/2017 on Special Treatment of Credit or Bank Financing for Certain Areas in Indonesia Affected by Natural Disasters. This OJK regulation was adopted by the Board of Commissioners in considering the following aspects. ${ }^{23}$

1. Confirmation that natural disasters that have hit various regions in Indonesia several times generally have a significant impact on economic growth in certain areas affected by natural disasters

2. Acknowledgment that Indonesia is geographically located in a vulnerable area affected by natural disasters that leads to potency for natural disaster

3. The belief that efforts to support recovery economic conditions may be carried out by granting special treatment of bank credit or financing with a certain amount and credit or financing restructured

4. The authority of OJK to re-arrangement of treatment specifically for bank credit or financing for the certain regions in Indonesia affected by natural disasters due to its functions, tasks, and regulatory authority and supervision of financial services at the banking sector

With regard to granting of credit, this regulation explains A bank may grant credit or financing and/or other provision of funds which is given after a

21 Ibid, Art. 28.

22 Hermansyah, Hukum Perbankan Nasional Indonesia, Edisi Kedua, Cetakan ke-8, Jakarta: Prenadamedia Group, 2014, 228.

23 Regulation of Indonesia Financial Servives Authority No. 45 /POJK.03/2017 on Special Treatment for Credit or Financing of Banks in Certain Regions of Indonesia that Are Affected by Natural Disasters, Part Consideration, a, b, c, d. 
disaster occurs to borrowers in certain regions of Indonesia affected by natural disasters. ${ }^{24}$

Article 6 of Regulation of Indonesian Financial Services Authority No. 45/POJK.03/2017 on Special Treatment of Credit or Bank Financing for Certain Areas in Indonesia Affected by Natural Disasters makes clear that determination of certain areas affected by natural disasters stipulated in a decision of the Authority Board of Commissioners Financial Services by paying attention to aspects:

a. the area affected by natural disasters;

b. the number of deaths;

c. amount of material loss;

d. the number of debtors expected to be affected by the natural disaster;

e. percentage of the amount of credit or financing provided to debtors affected by natural disasters

f. the amount of credit or financing in the area affected by natural disasters;

g. percentage of credit or financing with a ceiling of up to Rp 5.000.000.000,00 (five billion rupiahs) to the amount of credit or financing in areas affected by natural disasters; and

h. other aspects according to the Financial Services Authority need to be considered.

Pujiyono, M Najib Imannullah, Ryan Ganang Kurnia reveals a bank practice of restructuring bad loans as affected by natural disasters in the form of a reduction in credit principal arrears. Despite its expected effectivity, such practice is without any risks as it is the last resort of credit restructuring provided by banks because it is usually followed by the elimination of interest and total penalties. ${ }^{25}$

Credit Restructuring is an improvement effort made by the Bank in credit activities to debtors who have difficulties to fulfill its obligations, which are carried out among others through: 26

a. Reduction in loan interest rates;

b. Extension of credit period;

${ }^{24}$ Delloite, New Financial Services Authority (OJK) Regulations, The Summary of the New Financial Services Authority (OJK) Regulations, 3 August 2017 KM 6/8/2017

25 Pujiyono, M Najib Imannullah, Ryan Ganang Kurnia, loc.cit.

26 Regulation of Central Bank of Indonesia No. 14/ 15 /PBI/2012 concerning Assessment of Commercial Bank Asset Quality, Article 1 (26) 
c. Reduction in interest on Credit arrears;

d. Reduction of credit principal arrears;

e. Addition of credit facilities; and/or

f. Credit conversion into temporary equity participation.

In 2017 , several cities in Indonesia were affected by natural disasters, including earthquakes, volcanic eruptions, and flooding. In light of the circumstances, OJKtook action and issued a Board of Commissioners (hereinafter referred to as $\mathrm{BoC}$ ) Decree containing several policies for the special treatment of loans in disaster areas as follows: ${ }^{27}$

1. OJK BoC Decree No. 02/KDK.03/2017 on Designating Pidie Jaya as a Regency Requiring Special Bank Loan Treatment The regulation was issued to banks in natural disaster areas, in this case, Pidie Jaya regency that was affected by an earthquake. The provisions of the regulation stipulated that loan requirements would be relaxed in Pidie Jaya for three years from 20th January 2017.

2. OJK BoC Decree No. 03/KDK.03/2017 on Extending the Maturity of Bank Loans in several Districts of Karo as a Regency Requiring Special Bank Loan Treatment The regulation was issued to extend the maturity on bank loans in Payung, Nawanran, Simpang Ampat and Tiganderket districts in Karo as a regency requiring special bank loan status. The provisions of the regulation extended the maturity of bank loans in several districts of Karo by one year from 22nd January 2017.

3. OJK BoC Decree No. 04/KDK.03/2017 on Designating Bima as a City Requiring Special Bank Loan Treatment The regulation was issued to banks in natural disaster areas, in this case, Bima city, West Nusa Tenggara, that were affected by flash flooding. The provisions of the regulation stipulated that loan requirements would be relaxed in Bima for three years from 20th January 2017.

4. OJK BoC Decree No. 20/KDK.03/2017 on Designating Karangasem, Bali, as a Regency Requiring Special Bank Loan Treatment The regulation loosened the criteria to determine the quality of loans and restructured loans for borrowers affected by the Mount Agung volcanic eruption in Karangasem, Bali. The provisions of the regulation stipulated that loan requirements would be relaxed in Karangasem, Bali, for three years from 29th December 2017.

27 Indonesia Financial Services Authority 2017 Annual Report, 99-100 https://ojk.go.id/id/data-dan-statistik/laporantahunan/Documents/Laporan\%20Tahunan\%20OJK\%202017.pdf 
In August 2018 the Financial Services Authority (OJK) established a policy to provide special treatment for Islamic credit and financing from banking, for debtors or projects located in natural disaster locations in the Province of West Nusa Tenggara. ${ }^{28}$

Some economic impacts of natural disasters in Indonesia have challenged the role of OJK. In January 2019, The Chairman of the Indonesian People's Representative Council asked the government to help eliminate bank credit bills for around 10.000 debtors affected by the earthquake and tsunami disaster in Palu, Donggala and Sigi, South Sulawesi. The debtor whose business cannot run properly because of being hit by a disaster is difficult to start a business or pay for credit. The elimination policy is expected to not only ease the burden of victims of natural disasters but also to accelerate economic recovery in those areas. ${ }^{29}$ After the OJK BoC announced a Credit and financing payment relief policy for customers affected by the earthquake and tsunami victims in Central Sulawesi, a number of banks positively welcomed the loan repayment relief policy for customers who were victims of the Central Sulawesi natural disaster in order to restore the economy and financial services industry in the region. However, there are also concerns that this policy has the potential to be used by parties who have moral hazard intentions to avoid the obligation to repay loans from banks and other financial services industries. ${ }^{30}$

Recently, OJK releases Circular Letter of the Indonesian Financial Authority No. 1 / SEOJK.03/2019 on Application of Risk Management for Rural Banks, as a technical implementation of the Financial Services Authority Regulation No 13 / POJK.03 / 2015 concerning Application of Risk Management for Rural Banks, that alerts some issues of disaster. In this letter, OJK urges rural banks to adopt risk management policies that should at least include the creation of a contingency plan in the worst condition. It is a scenario development plan to anticipate internal disturbances including system

28 SP 54/DHMS/OJK/VIII/2018 Siaran Pers Perlakuan Khusus Terhadap Kredit Atau Pembiayaan Bank Dan Industri Jasa Keuangan Yang Terkena Bencana Alam Gempa Bumi Di Provinsi Nusa Tenggara Barat, https://www.ojk.go.id/id/berita-dan-kegiatan/siaranpers / Documents/Pages/Siaran-Pers-Perlakuan-Khusus-Terhadap-Nasabah-dan-OJKTerdampak-Gempa-NTB/siaran\%20pers\%20perlakuan\%20khusus\%20lombok.pdf

${ }^{29}$ DPR RI. Berita. Pemerintah Diharapkan Hapus Tagihan Kredit Perbankan Korban Bencana. Last modified January 2019. http://www.dpr.go.id/berita/detail/id/23557/t/Pemerintah+Diharapkan+Hapus+Tagihan+Kre dit+Perbankan+Korban+Bencana

30 Hukumonline.com. Berita. Begini Cara OJK Ringankan Kredit Korban Gempa Sulteng. Last modified October 11, 2018.

https://www.hukumonline.com/berita/baca/lt5bbf3916dcf6a/begini-cara-ojkringankan-kredit-korban-gempa-sulteng/ 
failure and external interference cause an emergency that can cause disruption to rural bank operations. In preparing an emergency plan, the rural bank must also develop a business continuity plan policy for possible conditions extern and worst internal, so business continuity rural bank can be maintained including a disaster recovery plan. ${ }^{31}$ In terms of policy and procedure, OJK expected rural banks to have business continuity management (BCM) as an integrated protocol and overall to ensure the continuity of rural banks their operations in conducting business and serving customers, for anticipating force conditions such as natural disasters, fire, robbery, or technical problems experienced by rural banks that affect the sustainability of their operations. ${ }^{32}$ Further, this circular letter also addresses that in identifying credit risk, it is necessary considered factors that can affect the level of risk future credit, as is possible changes in economic conditions, including changes in consequences natural disasters and government policies. ${ }^{33}$

The above analysis shows that in Indonesia the efforts of financial stabilisation in responding to the natural disaster is primarily taken by the OJK by issuing a relaxation policy. This may relatively differ from the practices in other countries. Vietnam law stipulates that rural households can receive a lump sum for the destruction of their house affected by a natural disaster. The government often increases this amount as it generally considered insufficient. 34 In Latin America, development organizations and private investors created a novel intermediary institution, the Emergency Liquidity Facility Mechanisms for financing the costs of disasters which acts as a lender of last resort by providing needed and immediate post-disaster liquidity to MFIs, This institution was developed as they realize that the risks of Post-disaster microcredit as it increases post-disaster demand that can challenge the liquidity of micro-credit organizations and tempt relaxed loan conditions or even debt pardoning. ${ }^{35}$ In Africa, economic constraints resulted from natural disasters are infrequently and incompletely reported that entails an underestimation of

31 Circular Letter of the Indonesian Financial Authority No. 1 / SEOJK.03/2019 on Application of Risk Management for Rural Banks, Section B.2.f.5)

${ }^{32}$ Ibid., Section C.2.h

33 Ibid., Section D.1.d

34 Ghesquiere, Francis and Mahul, Olivier, "Financial protection of the state against natural disasters: a primer." World Bank Policy Research Working Paper 5429 (2010).

35 Mechanisms for financing the costs of disasters Joanne Linnerooth-Bayer, Stefan Hochreiner-Stigler and Reinhard Mechler1 27 November 2012 Report produced for the Government Office of Science, Foresight project 'Reducing Risks of Future Disasters: Priorities for Decision Makers', 10-11. As a comparison, Bank-lending channel is that a relaxed monetary policy induces banks to provide more lending. SeeSantiago Carbó Valverde $\cdot$ Rafael López del Paso, Bank-Lending Channel and Non-Financial Firms: Evidence For Spain, Spanish Economic Review 11, No.2 (2009): 125-140. 
damage figures. The inefficiency of formal (state and market) institutions to handle natural disasters in this continent presents a major handicap for its development. 36

\subsection{The Implementation of OJK Rules in Bali and The Concern of Local Community}

OJK discovered that the distribution of credit from banks to communities on the island of Bali is still centered on the Municipality of Denpasar, Badung Regency, and Gianyar Regency while the other potential regencies for credit distribution are Bangli, Klungkung, dan Tabanan. ${ }^{37}$ Therefore, Karangasem regency is actually not part of those credit circulation in Bali. For Karangasem Regency in Bali Province, Decision OJK BoC No.20/KDK.03/2017 determines Karangasem Regency-Bali as an area that needs its special treatment of bank credit and is valid for three years since December 29, 2017.38

In general, banks will make efforts to overcome problem loans by way of rescheduling, reconditioning and restructuring. ${ }^{39}$ The following explanation reveals an example of how a public bank (commercial bank), namely BPD Bali in responding to the policy. The Head of BPD Bali Karangasem Branch said that OJK relaxation rules for credit due to the eruption of Mount Agung were quite significant. But the credit settlement process that can be carried out relaxation is the smooth one. OJK's rules regarding it are not fully implemented, because banks must choose and sort out loans that can be relaxed. Most relaxation is given to productive credit, even though there are some debtors seem do not need such measure as they can afford to pay even in the event of economic uncertainty. The bank does not apply such relaxation for consumer loans, especially for civil servants and other types of employees. Credit realization until December 2017 amounted to Rp 1.2 trillion with an NPL of 5.28\%, which was restructured at Rp 12.6 billion. Until the end of December 2018 , the realization of credit was Rp 1.2 trillion with an NPL of $4.24 \%$ which was restructured in the amount of Rp. 147, 4 billion. Looking at the data of the BPD Bali Karangasem branch, it can be assumed that in the period of 2017 to

36 Emmanuel Innocents Edoun, Roland Azibo Balgah \& Charles Mbohwa. "The Impact of Effective Management of Natural Disasters for Africa's Development." Economic ResearchEkonomska Istraživanja 28, no. 1 (2015): 924-938.

37 CNN Indonesia. Berita Keuangan. OJK Ungkap Tiga Kabupaten di Bali yang Paling Aktif Berutang. https://www.cnnindonesia.com/ekonomi/20160819162536-78-152496/ojkungkap-tiga-kabupaten-di-bali-yang-paling-aktif-berutang

38 Press Release of the Indonesian Financial Service Authority No. SP 01/DHMS/OJK/I/2018 on Special Policies For Banking in Karangasem Bali

39 Pujiyono, M Najib Imannullah, Ryan Ganang Kurnia, op.cit., 461. 
2018 the credit realization has not changed or remained, but there have been additional restructuring between 2017 and 2018, which included the result of OJK's loan relaxation rules. So that makes the NPL from 2017 and 2018 decline, which means that the performance of troubled loans also decreases in terms of quantity. Whatsoever, in the year 2019 BPD Bali optimistically targetted the credit will grow up until 9 percent, although in 2018 the realization was not 2 percent. The target is made based on the high allocation on kredit usaha rakyat (people's business credit) for mainly production sector (e.g tourism and agriculture) and trade sector, the supply chain financing (SCF), local government financing as well as a wish that there will be no natural disaster occurs anymore. 40

BPR performance in Bali grew slowly during the period of JanuarySeptember 2018 due to unstable economic growth and the process of banking consolidation continued as a result of the eruption of Mount Agung and the earthquake. The NPL ratio of BPRs in Bali until September 2018 reached 9.24 percent, up from the previous position of 7.82 percent, exceeding the national average of 7.16 percent. ${ }^{41}$ A leading rural bank in Bali, BPR Lestari organized a Focus Group Discussion with the topic of the handling of non performing loans and the impact of Mount Agung eruption by virtue of mapping the strategy to be applied in dealing with the situation faced. One of its bankers conveyed three aspects that become the focus in addressing the financial storm situation, namely credit quality, costs, and human resources. The FGD concluded that Central Bank of Indonesia and OJK rules have to be implemented that ensure the rural banks are in the right track. ${ }^{42}$

It cannot be denied that a utilitarian approach was used by OJK in the form of Banking-relaxation policy in supporting the local society affected by natural disaster. However, the OJK Rules seems to have not been fully implemented by both public and rural banks in Bali.

It can be argued that the uniqueness of the economic situation in Bali that is very much influenced by the peculiarity of its social and cultural life of

40 Tribunbali.com. Bisnis. BPD Bali Optimistis Target Pertumbuhan Kredit 9 Persen, OJK Segera Rampungkan Calon Dowan https://bali.tribunnews.com/2019/02/01/bpd-bali-optimistis-target-pertumbuhan-kredit-9persen-ojk-segera-rampungkan-calon-dewan-komisaris

41 Antara Bali. Berita. OJK: Kinerja BPR di Bali tumbuh melambat. Last modified December 4, 2018. https://bali.antaranews.com/berita/134345/ojk-kinerja-bpr-di-balitumbuh-melambat

42 BPR Lestari. Lestari News. Risiko Kredit Terus Naik, BPR Lestari Gelar Focus Group Discussion BPR Se-Indonesia. Last modified February 12, 2018. https://bprlestari.com/en/berita-lestari/risiko-kredit-terus-naik-bpr-lestari-gelar-focusgroup-discussion-bpr-se-indonesia?page $=17$ 
the local peoples has not to be taken into consideration by relevant financial authorities in issuing a policy to address financial problems faced by those who affected by natural disasters. The following narrations will explore three matters that were not seriously be addressed.

First of all, the concerns on cultural-economic issues. The majority of Bali population are Balinese Hindus who use parts of the money for practicing their religious, cultural, and tradition activities and supporting the establishment of temples. ${ }^{43}$ It has ever been studied that almost $60 \%$ of the budget is not used for meals consumption. ${ }^{44}$ Not all loan is used for initiating or developing the business as sometimes, they need a loan to support the incidental ceremonies such as cremation. ${ }^{45}$ As an example, in South Bali, a few years ago the cost of the simplest cremation ceremony was around IDR.10.000.000,- (currently is about US\$700) while the middle-level of cremation ceremonies may cost between IDR 50.000.000,- (US\$3.500) and IDR $60.000 .000,-$ (US\$ 4.250). A bunch of budgets mostly spent by the royalty who may reach hundreds of millions or even billions of Indonesian rupiah. 46

Second, in the context of local economies. Karangasem regency gained a lack of revenue that leads it becomes the lowest average economic growth rate compared to other regencies/municipality in Bali. ${ }^{47}$ Many potential residents of Karangasem choose to work in Southern are of Bali that more wealth in terms of economics, mainly Denpasar city and Badung regency. Despite the government has tried to initiate micro, small, and middle-size business in Karangasem regency in order to enable them to manage their own economic potency, the remaining residents are relatively struggling with their livelihood.

Third, in terms of the tourism industry. It is generally known that Bali is a tourist destination in which the tourism industry plays a main role in generating economics of the local society. Some travel advisory issued by foreign countries suggesting not to visit Bali due to this natural disaster has an

$43 \mathrm{Ni}$ Nyoman Alit Triani and Made Dudy Satyawan, "Memaknai Sisi Akuntansi Sumbangan Keagamaan Masyarakat Hindu Bali." Jurnal Akuntansi Multiparadigma 7, no. 2 (2016): 240-255.

44 Tirto.id. Sosial Budaya. Hampir 60\% Pengeluaran Masyarakat Bali Bukan untuk Makanan. https://tirto.id/hampir-60-pengeluaran-masyarakat-bali-bukan-untuk-makanan$\underline{\mathrm{clEb}}$

45 See Nengah Bawa Atmadja dan Tuty Maryat. "Geria Pusat Industri Banten Ngaben di Bali Perspektif Sosiologi Komodifikasi Agama." Jurnal Kawistara 4, no. 2 (2014): 111-224.

46 I Made Arsana. Bali's Ritual Economy. Center for Religious and Cross-cultural Studies, Universitas Gadjah Mada, Yogyakarta, https://crcs.ugm.ac.id/balis-ritual-economy/

$47 \mathrm{Ni}$ Made Winda Savitri Dewi and I Nyoman Mahaendra Yasa. Analisis Sektor Potensial Dalam Menetapkan Perencanaan Pembangunan di Kabupaten Karangasem. E-Jurnal Ekonomi Pembangunan Universitas Udayana 7, no.1 (2018): 152-183. 
impact on the decreasing numbers of visitors that leads to fragile and uncertainty economic situation. As an illustration, in December 2017 there was $21 \%$ decrease in room occupancy in Bali, and if the average room price in Bali is around IDR 1 million, the total lost is around IDR 1.100 billion, that affect $80 \%$ of the people in Bali whose economically dependent on the tourism sector. 48

The fact is that Karangasem Regency is like a 'newbie' in developing the tourism industry compared to Badung, Denpasar, and Gianyar. Most tourists prefer to stay in the Southern part of Bali, close to the international airport and famous tourist attractions, leaving Karangasem regency as a secondary option to stay. It entails an unstable income for Karangasem residents who work in the field of the tourism industry that would have an impact on their ability to perform their loans.

These three reasons may raise an understanding that the OJK financial relaxation policy may have an impact on the general and rural banks in the context of loan policy. The policy also seems to help local society, especially those who have an obligation for loan performance, but temporarily. However, this utilitarian policy cannot solve the economic problems faced by local society affected by Mount Agung eruptions, especially Karangasem residents, as the abovementioned issues have not to be taken into account.

\section{Conclusion}

Based on Indonesian Law, the performance of obligation raises from a contractual agreement may be waived in case of a natural disaster. This is generally known as a 'force majeure' condition that in most contracts, appears as a specific clause. The present article argues that local society who affected by the eruption of Mount Agung in Karangasem Regency-Bali may use 'force majeure' to suspend their obligation performance in any economic matters, including loan banking. This private law concern has been realized by the Indonesian Financial Service Authority that has issued a Commissioner Board Decision in addressing the impact of such disaster in Bali. The decision is a kind of relaxation financial policy for the period of 3 years that is expected to give flexibility to local society to re-arrange their economic situation after the disaster. It seems that such a policy has not properly been implemented by all banks in a related area. A utilitarian approach that inspired the OJK relaxation policy seems to need to be adjusted by considering the concerns on cultural-

48 Putu Indah Rahmawati, Nana Trianasari, A.A.Ngr.Yudha Martin, "The Economic Impact of Mount Agung Eruption on Bali Tourism." In International Conference on Tourism, Economics, Accounting, Management, and Social Science (TEAMS 2018). Atlantis Press, 2019: 98-107. 
economic issues, the real declining and uncertain situation of the local economy, and the fragile tourism industry in Karangasem regency.

\section{Acknowledgment}

Author would like to recognize the role of Maheswara Sukawati Perbawa for doing technical aspects of this publication.

\section{BIBLIOGRAPHY}

\section{Book}

Hermansyah. Hukum Perbankan Nasional Indonesia. Edisi Kedua, Cetakan ke8. Jakarta: Prenadamedia Group, 2014.

Sutedi, Adrian. Aspek Hukum Otoritas Jasa Keuangan. Jakarta: Raih Asa Sukses, 2014.

\section{Journal Article}

Isradjuningtias, Agri Chairunisa. Force Majeure (Overmacht) Dalam Hukum Kontrak (Perjanjian) Indonesia, Veritas et Justitia1 no.1 (2015): 136154, https://doi.org/10.25123/vej.1420

Bos, Jaap, Runliang Li, and Mark Sanders. "Hazardous Lending: The Impact of Natural Disasters on Banks' Asset Portfolio." (2018).

Dewi, Ni Made Winda Savitri and I Nyoman Mahaendra Yasa. Analisis Sektor Potensial Dalam Menetapkan Perencanaan Pembangunan di Kabupaten Karangasem. E-Jurnal Ekonomi Pembangunan Universitas Udayana 7, no.1 (2018): 152-183.

Edoun, Emmanuel Innocents, Roland Azibo Balgah, and Charles Mbohwa. "The Impact of Effective Management of Natural Disasters for Africa's Development." Economic Research-Ekonomska Istraživanja 28, no. 1 (2015): 924-938. https://doi.org/10.1080/1331677X.2015.1087325

Ghesquiere, Francis, and Olivier Mahul. "Financial Protection of the State Against Natural Disasters: A Primer." World Bank Policy Research Working Paper 5429 (2010).

Hadi, Haeva, Zainal Asikin, and Muhammad Sood. "Agreement on Home Loan (KPR) Due to Natural Disaster (Case Study in North Lombok Regency)." International Journal of Multicultural and Multireligious Understanding 6, no. 3 (2019): 267-276, http://dx.doi.org/10.18415/ijmmu.v6i3.824

Atmadja, Nengah Bawa. "Geria Pusat Industri Banten Ngaben di Bali Perspektif Sosiologi Komodifikasi Agama." Jurnal Kawistara 4, no. 2 (2014): 111224.

Triani, Ni Nyoman Alit, and Made Dudy Satyawan. "Memaknai Sisi Akuntansi Sumbangan Keagamaan Masyarakat Hindu Bali." Jurnal Akuntansi Multiparadigma $7, \quad$ no. 2 (2016): 240-255, http://dx.doi.org/10.18202/jamal.2016.08.7019 
Silber, Norman I. "Debts, Disasters, and Delinquencies: A Case for Placing a Mandatory Force Majeure Provision into Consumer Credit Agreements." NYU Rev. L. \& Soc. Change 34 (2010): 760-792.

Noth, Felix, and Ulrich Schüwer. "Natural Disaster and Bank Stability: Evidence From the US Financial System." SAFE Working Paper, No. 167. (2018).

Pujiyono, Pujiyono, Moch Najib Imanullah, and Ryan Ganang Kurnia. "Problematika Pelaksanaan POJK Nomor 45/POJK. 03/2017 Dalam Penyelesaian Kredit Kecil dan Mikro Yang Macet Karena Bencana Alam." Jurnal IUS Kajian Hukum dan Keadilan 6, no. 3 (2018): 456-467, http://dx.doi.org/10.29303/ius.v6i3.579

Siahaan, Rudy Haposan. "Natural Disaster as The Reason To Writing Off Banking Credit In Indonesia." Brawijaya Law Journal 1, no. 1 (2014): 14-25, http://dx.doi.org/10.21776/ub.blj.2014.001.01.02

Valverde, Santiago Carbó, and Rafael López Del Paso. "Bank-Lending Channel and Non-Financial Firms: Evidence for Spain." Spanish Economic Review 11, no. 2 (2009): 125-140. https://doi.org/10.1007/s10108008-9046-6

Schüwer, Ulrich, Claudia Lambert, and Felix Noth. "How Do Banks React to Catastrophic Events? Evidence from Hurricane Katrina." Review of Finance 23, no. 1 (2018): 75-116, https://doi.org/10.1093/rof/rfy010

\section{Proceeding}

Rahmawati, Putu Indah, Nana Trianasari, and AA Ngr Yudha Martin. "The Economic Impact of Mount Agung Eruption on Bali Tourism." In International Conference on Tourism, Economics, Accounting, Management, and Social Science (TEAMS 2018). Atlantis Press, 2019: 98-107, https://doi.org/10.2991/teams-18.2019.18

\section{Regulations, Reports, and Documents}

Law of the Republic of Indonesia No. 21 Year 2011 on Financial Services Authority

Regulation of Central Bank of Indonesia No. 14/ 15 /PBI/2012 concerning Assessment of Commercial Bank Asset Quality

Regulation of Indonesia Financial Services Authority No. 45 /POJK.03/2017 on Special Treatment for Credit or Financing of Banks in Certain Regions of Indonesia that Are Affected by Natural Disasters

Decree of Board of Commissioner of Indonesia Financial Services Authority No. 20/KDK.03/2017 on the Determination of the Regency of Karangasem Bali as an Area that Needs Special Treatment of Bank Credit

Circular Letter of the Indonesian Financial Authority No. 1 / SEOJK.03/2019 on Application of Risk Management for Rural Banks

Indonesia Financial Services Authority 2017 Annual Report

Siaran Pers SP 54/DHMS/OJK/VIII/2018 Siaran Pers Perlakuan Khusus Terhadap Kredit Atau Pembiayaan Bank Dan Industri Jasa Keuangan 
Yang Terkena Bencana Alam Gempa Bumi di Provinsi Nusa Tenggara Barat,

Press Release of the Indonesian Financial Service Authority No. SP 01/DHMS/OJK/I/2018 on Special Policies For Banking in Karangasem Bali

Press Release of the Indonesian Financial Service Authority

Delloite, New Financial Services Authority (OJK) Regulations, The summary of the new Financial Services Authority (OJK) regulations, 3 August 2017 KM 6/8/2017

Joanne Linnerooth-Bayer, Stefan Hochreiner-Stigler and Reinhard Mechler, Mechanisms for financing the costs of disasters, Report produced for the Government Office of Science, Foresight project 'Reducing Risks of Future Disasters: Priorities for Decision Makers, 27 November 2012

\section{Website Content}

DPR RI. Berita. Pemerintah Diharapkan Hapus Tagihan Kredit Perbankan Korban Bencana. http://www.dpr.go.id/berita/detail/id/23557/t/Pemerintah+Diharapk an+Hapus+Tagihan+Kredit+Perbankan+Korban+Bencana

Hukumonline.com. Berita. Begini Cara OJK Ringankan Kredit Korban Gempa Sulteng. https://www.hukumonline.com/berita/baca/1t5bbf3916dcf6a/beginicara-ojk-ringankan-kredit-korban-gempa-sulteng/

CNN Indonesia. Berita Keuangan. OJK Ungkap Tiga Kabupaten di Bali yang Paling Aktif Berutang https://www.cnnindonesia.com/ekonomi/20160819162536-78152496/ojk-ungkap-tiga-kabupaten-di-bali-yang-paling-aktif-berutang

Antara Bali. Berita. OJK: Kinerja BPR di Bali tumbuh melambat.. https://bali.antaranews.com/berita/134345/ojk-kinerja-bpr-di-balitumbuh-melambat

I Made Arsana. Bali's Ritual Economy. Center for Religious and Cross-cultural Studies, Universitas Gadjah Mada, Yogyakarta, https://crcs.ugm.ac.id/balis-ritual-economy/

Tirto.id. Sosial Budaya. Hampir 60\% Pengeluaran Masyarakat Bali Bukan untuk Makanan. https://tirto.id/hampir-60-pengeluaran-masyarakatbali-bukan-untuk-makanan-clEb

Nusabali.com. Berita. Kredit Bermasalah di Bali Lampaui Nasional. https://www.nusabali.com/berita/25259/kredit-bermasalah-di-balilampaui-nasional 
wartaekonomi.co.id. kabar Fianansial. Perbarindo Harapkan Dampak Gunung Agung Tidak Pengaruhi NPL. Last modified December 10, 2017. https://www.wartaekonomi.co.id/read163744/perbarindo-harapkandampak-gunung-agung-tidak-pengaruhi-npl.html

bali.bisnis.com. Bisnis Bali dan Nusra. Karangasem Resmi Ajukan Relaksasi Kredit. Last modified November 6, 2017. https://bali.bisnis.com/read/20171106/538/772049/karangasemresmi-ajukan-relaksasi-kredit

Oke Finance. Economy. OJK Diminta Bebaskan Bunga Kredit bagi Pengungsi Gunung Agung. Last modified December 26, 2017. https://economy.okezone.com/read/2017/12/26/320/1835879/ojkdiminta-bebaskan-bunga-kredit-bagi-pengungsi-gunung-agung

Hukumonlie.com. Berita. OJK Tetapkan Karangasem Bali dalam Perlakuan Khusus Soal Kredit Bank. Last modified January 3, 2018. https://www.hukumonline.com/berita/baca/lt5a4c8d7c228b4/ojktetapkan-karangasem-bali-dalam-perlakuan-khusus-soal-kredit-bank/

Gatra.com. News. Begini Detil Perlakuan Khusus OJK bagi Nasabah dan Industri Jasa Keuangan Korban Bencana Palu, Donggala, dan Sigi. Last modified October $10,2018$. https://www.gatra.com/detail/news/353484-Begini-Detil-PerlakuanKhusus-OJK-bagi-Nasabah-dan-Industri-Jasa-Keuangan-KorbanBencana-Palu-Donggala-dan-Sigi

BPR Lestari. Lestari News. Risiko Kredit Terus Naik, BPR Lestari Gelar Focus Group Discussion BPR Se-Indonesia. Last modified February 12, 2018. https://bprlestari.com/en/berita-lestari/risiko-kredit-terus-naik-bprlestari-gelar-focus-group-discussion-bpr-se-indonesia?page $=17$

Tribunbali.com. Bisnis. BPD Bali Optimistis Target Pertumbuhan Kredit 9 Persen, OJK Segera Rampungkan Calon Dewan Komisaris. Last modified February 2017. https://bali.tribunnews.com/2019/02/01/bpd-bali-optimistis-targetpertumbuhan-kredit-9-persen-ojk-segera-rampungkan-calon-dewankomisaris

Contract $\quad$ Standarts. $\quad$ Clauses. $\quad$ Force $\quad$ Majeure. https://www.contractstandards.com/public/clauses/force-majeure

\section{Dictionary}

Cambridge

Dictionary. https://dictionary.cambridge.org/dictionary/english/force-majeure Merriam-Webster. https://www.merriamwebster.com/dictionary/force\%20majeure 